\title{
PERSEPSI, POLA PENGASUHAN, DAN PERAN SERTA \\ KELUARGA PEMULUNG TENTANG PENDIDIKAN ANAK USIA DINI (STUDI DESKRIPTIF PADA KELUARGA PEMULUNG DIKAMPUNG CIBATU DESA CILAME KECAMATAN NGAMPRAH KABUPATEN BANDUNG BARAT)
}

\author{
${ }^{1)}$ Lenny Nuraeni, ${ }^{2)}$ Fifiet Dwi Tresna Santana \\ ${ }^{1)}$ lennynuraeni86@gmail.com
}

Program Studi Pendidikan Guru PAUD, STKIP Siliwangi

\begin{abstract}
ABSTRAK
Persepsi, pola pengasuhan dan peran serta keluarga pemulung tentang pendidikan anak usia dini (studi deskriptif pada keluarga pemulung di Kampung Cibatu Desa Cilame Kecamatan Ngamprah Kabupaten Bandung Barat). Kajian Teoritik Laporan ini terdiri dari konsep persepsi, Konsep Keluarga, Konsep Pola Asuh Orang Tua, Konsep Pendidikan Anak Usia Dini, Konsep Peran Serta Orang Tua. Penelitian menggunakan metode studi kasus yaitu menekankan pada aspek tertentu yang dikaji secara mendalam. Adapun pendekatan yang diambil adalah pendekatan kualitatif, karena pada hakekatnya penelitan ini bertujuan untuk menganalisis dan menafsirkan suatu fakta, gejala dan peristiwa berdasarkan apa yang terjadi dilapangan mengenai "Bagaimana Persepsi Keluarga Pemulung tentang Pendidikan Anak Usia Dini (Studi pada Keluarga Pemulung di Kampung Cibatu Desa Cilame Kecamatan Ngamprah Kabupaten Bandung Barat Barat)". Dari hasil penelitian diperoleh hasil bahwa kesimpulan sebagai berikut :1) Persepsi Keluarga Pemulung tentang Pendidikan Anak Usia Dini: Harapan keluarga pemulung yang paling terbesar adalah kelak anak-anak mereka dapat menyelesaikan sekolah mereka dengan baik, dan berprestasi serta mendapatkan pekerjaan yang lebih baik dari orang tua mereka, sehingga mereka dapat keluar dari garis kemiskinan dan pada akhirnya meningkatkan derajat keluarga mereka ditengah-tengah masyarakat. Namun dikenyataannya bahwa keluarga pemulung masih melibatkan anak-anak mereka dalam mencari nafkah, dimana para orang tua tidak memberikan waktu bagi anak-anak mereka untuk bermain dan belajar dengan baik tanpa harus ikut memikirkan dan berusaha dalam memenuhi kebutuhan hidup mereka, 2) Pola pengasuhan Anak Usia Dini (AUD) yang dilakukan oleh keluarga pemulung yang mengikutsertakan anaknya ke lembaga PAUD adalah dominan menggunakan pola pengasuhan demokratis, sedangkan pola pengasuhan yang dilakukan oleh keluarag pemulung yang tidak mengikutsertakan anaknya ke lembaga PAUD adalah Otoriter dan Laizes Faire dan pengasuhan yang lebih dominan terhadap anak yaitu dilakukan oleh ibu, 3) Peran serta orang tua (keluarga pemulung) dalam program PAUD di masyarakat. Semua keluarga pemulung di Kampung Cibatu Desa Cilame Kecamatan Ngamprah Kabupaten Bandung Barat memberikan partisipasi tenaga. Hal tersebut dikarenakan partisipasi dalam bentuk tenaga merupakan partisipasi yang murah dan mudah diberikan oleh keluarga pemulung. Sebagian besar keluarga pemulung memberikan partisipasinya dalam bentuk ketrampilan dan kemahiran serta sosial. Bagi keluarga pemulung yang menyertakan anaknya ke lembaga PAUD, hanya dapat membantu melalui ketrampilan yaitu membuat mainan dari barang-barang bekas serta sosial yaitu berupa menyebarkan informasi-informasi seputar penyelenggaraan kegiatan-kegiatan di PAUD.
\end{abstract}

Kata Kunci: Persepsi, Pola Pengasuhan dan Peran Serta Keluarga Pemulung tentang Pendidikan Anak Usia Dini.

\begin{abstract}
Perception, parenting and the role of scavenger families about early childhood education (descriptive studies on scavenger families in Kampung Desa Cibatu Cilame Ngamprah District of West Bandung regency). Theoretical study report consists of the concept of perception, Family Concept, Concept Parenting Parents, Early Childhood Education Concept, Concept of Participation of Parents. Research using the case study method is particular emphasis on aspects studied in depth. The approach taken is a qualitative approach, because in essence this research aims to analyze and interpret the facts, symptoms
\end{abstract}


and events based on what is happening in the field of "How Perception of Family Scavenger on Early Childhood Education (Studies in Family Scavenger Kampung Cibatu Village Cilame Ngamprah subdistricts of West Bandung Regency West) ". From the research results that the following conclusions: 1) Perception of Family Scavenger on Early Childhood Education: Hope family scavenger most biggest is the future of their children can finish their school well, and achievement as well as getting a better job than people their parents, so that they can get out of poverty and ultimately improving the degree of their families in the midst of society. However dikenyataannya that family scavenger still involve their children in making a living, where parents did not allow time for their children to play and learn well without having come to think and try to meet their needs, 2) the pattern of parenting Children Early (AUD) conducted by the family of scavengers who engage their children to institutions of early childhood education is the dominant use nurture democratic, whereas parenting is done by keluarag scavengers that do not involve their children to institutions of early childhood education is authoritarian and Laizes Faire and nurturing more dominant against children that is carried by the mother, 3) participation of parents (family scavenger) in early childhood education programs in the community. All scavenger families in Kampung Desa Cibatu Cilame Ngamprah District of West Bandung regency give force participation. That is because participation in the form of labor is cheap and easy participation by family scavengers. Most families scavengers provide participation in the form of skills and social skills as well. For the scavenger families encourage their children to early childhood institutions, can only be helped through skills that make toys of second-hand goods in the form of social and disseminate information about the implementation of activities in early childhood.

Keywords: Perception, Parenting and Family Participation Scavengers on Early Childhood Education.

\section{A. PENDAhuluan}

\section{Latar Belakang Masalah}

Berbagai jenis pekerjaan dilakukan oleh manusia dalam rangka kehidupannya. Salah satu jenis pekerjaan tersebut adalah pemulung. Profesi ini berhubungan dengan masalah yang akan diteliti oleh penulis. Di Kampung Cibatu Desa Cilame Kecamatan Ngamprah Kabupaten Bandung Barat terdapat pemukiman pemulung, pemulung disini yaitu orang-orang yang bermata pencaharian hidup dengan mengumpul dan membeli barang-barang bekas dari rumah penduduk dan tempat penampungan sampah penduduk yang memiliki prospek daur ulang atau reproduksi. Tak jarang pula mereka mengumpulkan sampah-sampah organik dari rumah tangga yang pada akhirnya akan dijadikan pakan ternak.

Kemajuan suatu bangsa tidak terlepas dari kemajuan pribadi manusia itu manusia yang ada di dalam bangsa tersebut. Hal tersebut tidak terlepas dari Pembangunan Nasional yang pada dasarnya merupakan pembangunan manusia seutuhnya yang mengutamakan kemajuan. Sehingga upaya untuk mewujudkan hal tersebut di atas, salah satu upaya yang paling mendasar dalam rangka mengembangkan potensi bangsa adalah melalui jalur pendidikan. Sebagaimana yang tercantum dalam Undang-undang No.20 tahun 2003 tentang Sistem Pendidikan Nasional adalah :
Pendidikan adalah usaha sadar dan terencana untuk mewujudkan suasana belajar dan proses pembelajaran agar peserta didik secara aktif mengembangkan potensi dirinya untuk memiliki kekuatan spiritual keagamaan, pengendalian diri, kepribadian, kecerdasan, akhlak mulia, serta keterampilan, yang di perlukan dirinya, masyarakat, bangsa dan Negara". Sedangkan, menurut Kleis (1974), seperti yang dikutip Djudju Sudjana (2004: 25) Pendidikan adalah : "Sejumlah pengalaman yang dengan pengalaman itu, seseorang atau sekelompok orang dapat memahami sesuatu yang sebelumnya tidak mereka pahami”.

Dunia pendidikan sebagai salah satu komponen penunjang untuk memperoleh pengalaman dalam hidup dan berperan cukup besar untuk menciptakan manusia yang berkualitas. Kalangan pendidikan mungkin sudah paham dan meraihnya dalam dunia pendidikan di Indonesia bisa diperoleh melalui tiga jalur yaitu: Jalur Pendidikan formal, nonformal, dan informal. Tiga jalur pendidikan ini saling mengisi satu sama lain dalam menciptakan Sumber Daya Manusia yang berkualitas..

Sesuai dengan UU Nomor 20 Tahun 2003 dan peraturan pemerintah Nomor 27 Tahun 1990. Guna mendukung hal tersebut upaya pemerataan dan peluasan serta peningkatan mutu dan pelayanan pendidikan bagi anak usia dini pemerintah mulai mengembangkan proyek pengembangan anak usia dini (PAUD). PAUD sebagai salah satu bentuk pendidikan prasekolah dengan mengutamakan 
bermain sambil belajar secara individual dan kelompok melalui kegiatan aktif. Sedangkan pengertian pendidikan anak usia dini diterangkan dalam UU RI No.20 Tahun 2003 tentang sistem pendidikan nasional sebagai berikut:

Pendidikan anak usia dini adalah upaya pembinaan yang ditunjukan kepada anak sejak lahir sampai usia enam tahun yang dilakukan melalui pemberian rangsangan pendidikan untuk membantu pertumbuhan dan perkembangan jasmani dan rohani agar anak memiliki kesiapan dalam memasuki pendidikan lebih lanjut.

Pendidikan merupakan suatu kegiatan universal dalam kehidupan manusia. Pada hakikatnya, pendidikan merupakan usaha manusia untuk memanusiakan manusia itu sendiri, yaitu untuk membudayakan manusia. Meskipun pendidikan merupakan suatu gejala yang umum dalam setiap kehidupan masyarakat, namun perbedaan filsafat dan pandangan hidup yang dianut oleh masingmasing bangsa atau masyarakat dan bahkan individu menyebabkan perbedaan penyelenggaraan kegiatan pendidikan tersebut.

Dengan demikian selain bersifat universal pendidikan juga bersifat nasional. Sifat nasionalnya akan mewarnai penyelenggaraan pendidikan itu. Life long education, kalimat yang sering kita kenal sejak dulu sampai sekarang, yang artinya "Pendidikan sepanjang hayat", dalam ajaran agamapun juga disebutkan "Tuntutlah ilmu mulai dari ayunan sampai ke liang lahat". Semua itu menjelaskan bahwa pendidikan telah menjadi kebutuhan pokok bagi manusia. Pentingnya pendidikan tidak hanya untuk disuarakan dan disiarkan melalui kalimat dan jargon, namun perlu langkah nyata dalam kehidupan.

Kebijakan-kebijakan dalam sistem pendidikan harus memenuhi unsur aktualisasi dan berdaya guna. Konsep pendidikan sepanjang hayat menjadi panduan dalam meninggikan harkat dan martabat manusia. Anak-anak bangsa ini tidak boleh tertinggal dengan bangsa lainnya di dunia. Oleh karena itu, pendidikan sejak dini harus ditanamkan kepada mereka. Salah satu kebijakan pemerintah di sektor pendidikan yang mendukung pendidikan sepanjang hayat adalah diakuinya Pendidikan Anak Usia Dini (PAUD).

PAUD adalah pendidikan yang cukup penting dan bahkan menjadi landasan kuat untuk mewujudkan generasi yang cerdas dan kuat. PAUD merupakan salah satu bentuk penyelenggaraan pendidikan yang menitikberatkan pada peletakan dasar ke arah pertumbuhan dan perkembangan fisik (koordinasi motorik halus dan kasar), kecerdasan (daya pikir, daya cipta, kecerdasan emosi, kecerdasan spiritual), sosio emosional (sikap dan perilaku serta agama) bahasa dan komunikasi, sesuai dengan keunikan dan tahap-tahap perkembangan yang dilalui oleh anak usia dini. Karena pada waktu manusia lahir, kelengkapan organisasi otak yang memuat 100-200 milyar sel otak siap dikembangkan serta diaktualisasikan untuk mencapai tingkat perkembangan potensi tertinggi. Periode sensitif perkembangan otak manusia terjadi pada interval umur 3-10 bulan.

PAUD berfungsi membina, menumbuhkan dan mengembangkan seluruh potensi anak usia dini secara optimal sehingga terbentuk perilaku dan kemampuan dasar sesuai dengan tahap perkembangannya. Agar memiliki kesiapan untuk memasuki pendidikan selanjutnya dalam rangka mencapai tujuan Pendidikan Nasional yang berbunyi: Pendidikan Nasional berfungsi mengembangkan kemampuan dan membentuk watak serta peradaban bangsa yang bermartabat dalam rangka mencerdaskan kehidupan bangsa bertujuan untuk berkembangnya potensi peserta didik agar menjadi manusia yang beriman dan bertaqwa kepada Tuhan yang Maha Esa, berakhlak mulia, sehat, berilmu, cakap, kreatif,mandiri, dan menjadi warga negara yang demokratis serta bertanggungjawab.

Tetapi bagi masyarakat keluarga miskin memilih menyekolahkan anak merupakan beban yang berat. ILO dan UNICEF juga menyatakan bahwa kesempatan mendapatkan pendidikan bagi anakanak miskin terbatas dan biayanya masih dirasakan mahal. Mutu pendidikan yang rendah mengakibatkan anak-anak tidak mempunyai motivasi untuk tetap sekolah.

Menurut Nimrah (2007) berdasarkan pengamatan dan informasi yang didapat di lapangan, untuk masalah pendidikan, anak-anak pemulung umumnya terbilang rendah. Pendidikan mereka paling tinggi hanya sebatas SMP. Faktor utamanya adalah dikarenakan tidak memiliki biaya.

Sekalipun faktor kemiskinan sangat besar terhadap anak-anak yang tidak bersekolah, kemiskinan bukan satu-satunya faktor yang berpengaruh. Salah satu faktor yang berpengauh adalah pola pikir yang pendek dan sederhana akibat rendahnya pendidikan. Dalam Budaya Indonesia, kepala 
rumah tangga terutama seorang ayah memiliki peranan yang besar dalam rumah tangga termasuk mengambil keputusan boleh atau tidaknya seorang anak untuk memperoleh pendidikan. Untuk mengambil keputusan tersebut tentunya akan sangat tergantung kepada persepsi atau pandangan orang tua terhadap pendidikan, terutama pendidikan anak usia dini.

Keluarga merupakan satuan unit sosial yang terdiri dari ayah, ibu, anak dan anggota keluarga lainnya, mempunyai arti yang sangat penting dalam pembentukan kepribadian anak dikemudian hari. Dalam lingkungan keluarga seseorang akan mempelajari sistem pengetahuan tentang normanorma yang berlaku serta kedudukan dan peran yang diharapkan oleh masyarakat. Setiap kedudukan dan peran memberikan hak untuk mencari apa yang tidak boleh dilakukan serta kewajiban-kewajiban apa yang harus dilakukan bagi warga dalam lingkungan sosial tertentu. Oleh karena itu penanaman nilai budaya dalam keluarga merupakan dasar utama dalam pembentukan pribadi anak.

Penanaman nilai-nilai budaya pada anak bukan hanya sekedar merawat, mengawasi saja melainkan lebih dari itu yaitu meliputi pendidikan, sopansantun, disiplin, tanggung jawab, mandiri, pengetahuan dan sebagainya yang bersumber kepada pengetahuan kebudayaan serta pendidikan yang diberikan orang tuanya. Di Kampung Cibatu Desa Cilame Kecamatan Ngamprah Kabupaten Bandung Barat Baratterdapat komunitas pemulung. Pada komunitas ini bukan hanya orang tua saja yang bekerja memenuhi kebutuhan hidup seharihari, melainkan anak-anak juga turut serta membantu.

Ketertarikan penulis untuk menjadikan komunitas ini sebagai objek penelitian adalah berdasarkan hasil survey yang telah dilakukan yaitu dari 18 keluarga kampung Cibatu yang bermata pencaharian sebagai pemulung, dan terdapat 15 keluarga yang memiliki anak usia dini. Dari data yang didapat bahwa dari 15 keluarga tersebut yang memiliki anak usia dini, 5 diantaranya mengikuti pendidikan anak usia dini, sehingga hanya $33 \%$ dari jumlah anak-anak yang berusia (0-6 tahun) yang mengikuti pendidikan anak usia dini.

Hal ini menunjukkan bahwa meskipun anak-anak sering mengikuti orang tua mereka dalam mencari nafkah namun mereka tetap mengikuti pendidikan yang saat ini sangat penting terhadap pembentukan kepribadian serta penanaman nilai-nilai moral, spiritual dan perkembangan-perkembangan seluruh aspek kecerdasan. Memulung bukanlah hambatan bagi mereka untuk mengenyam pendidikan walaupun dengan kondisi ekonomi keluarga yang tidak berkecukupan.

Berdasarkan pemikiran dan pernyataan tersebut di atas, penulis memandang bahwa mata pencaharian sebagai pemulung tidak menyurutkan mereka untuk mendidik anak-anak mereka menjadi lebih baik. Berangkat dari pemikiran inilah penulis ingin mengetahui lebih jauh tentang "Persepsi Keluarga Pemulung tentang Pendidikan Anak Usia Dini (Studi pada Keluarga Pemulung di Kampung Cibatu Desa Cilame Kecamatan Ngamprah Kabupaten Bandung Barat Barat)"..

\section{Tujuan}

Adapun yang menjadi penelitian ini, antara lain:

a. Untuk mengetahui persepsi orang tua tentang anak usia dini pada keluarga pemulung;

b. Untuk mengetahui pola pengasuhanAnak Usia Dini (AUD) yang dilakukan oleh keluarga pemulung;

c. Untuk mengetahui peran serta orang tua (keluarga pemulung) dalam program PAUD di masyarakat.

\section{Manfaat Penelitian}

Dari hasil penelitian ini penulis berharap dapat memberikan manfaat sebagai berikut:

a. Dari segi teoritis, penelitian ini diharapkan dapat memberikan sumbangan bagi pendidikan luar sekolah dan memperkaya hasil penelitian yang telah ada dan dapat memberi gambaran mengenai Persepsi Keluarga Pemulung Terhadap Pendidikan Anak Usia Dini, di Kampung Cibatu Desa Cilame Kecamatan Ngamprah Kabupaten Bandung Barat Barat.

b. Dari segi praktis, hasil penelitian ini diharapkan dapat membantu memberikan informasi khususnya kepada tutor dan para orang tua, dalam mengetahui Persepsi Keluarga Pemulung Terhadap Pendidikan Anak Usia Dini, di Kampung Cibatu Desa Cilame Kecamatan Ngamprah Kabupaten Bandung Barat Barat. 


\section{B. KAJIAN TEORI DAN METODE}

\section{Kajian Teori}

\section{a. Konsep Persepsi}

Persepsi adalah proses yang menyangkut masuknya pesan atau informasi ke dalam otak manusia melalui persepsi, manusia terus menerus mengadakan hubungan dengan inderanya, yaitu indera penglihatan, pandangan, peraba, dan penciuman. Persepsi erat kaitannya dengan perilaku dalam melibatkan atau menjabarkan.

Dari uraian diatas dapat ditarik kesimpulan bahwa persepsi pada intinya merupakan suatu pengamatan melalui penginderaan terhadap suatu objek, kemudian diteruskan oleh syaraf-syaraf sensoris ke otak. Di dalam otak, hasil pengamatan diproses secara sadar sehingga individu yang bersangkutan dapat menyadari dan memberikan objek yang diamati sesuai dengan perhatian, kebutuhan, sistem nilai dan karakteristik kepribadian

\section{b. Konsep Keluarga}

Dalam kehidupan sehari-hari manusia saling berinteraksi dan berkomunikasi. Proses interaksi dan komunikasi ini bertujuan untuk memenuhi kebutuhan hidupnya dan untuk memenuhi kewajibannya sebagai makhluk sosial. Pada hakekatnya hampir seluruh perilaku manusia bersifat sosial yaitu dipelajari dalam interaksi dengan manusia lainnya, baik di rumah, sekolah, tempat permainan/pekerjaan. Dengan adanya sifat sosial tersebut maka manusia dituntut untuk mengadakan ikatan-ikatan sosial dengan manusia lainnya, ikatan sosial yang paling penting dan paling besar adalah keluarga yang memiliki norma dan aturan yang berlaku.

Keluarga diartikan bermacam-macam, ada yang dikaitkan dengan hubungan darah, hubungan sosial, pandangan psikologis, biologis, maupun paedagogis. Secara sosiologis keluarga diartikan sebagai satuan sosial terkecil di dalam masyarakat, yang terdiri dari ayah, ibu dan anak. Sehubungan dengan hal itu, Mc Iver dan Page (M. I Soelaeman, 1994: 9) mengemukakan lima ciri khas keluarga yaitu : Adanya hubungan berpasangan antara pria dan wanita, Dikukuhkan oleh suatu pernikahan, Adanya pengakuan terhadap keturunan (anak) yang dilahirkan dalam hubungan tersebut, Adanya kehidupan ekonomi yang diselenggarakan bersama, Diselenggarakan kehidupan berumah tangga

\section{c. Konsep Pola Asuh Orang Tua}

Helmilia (2006:14) mengartikan pengasuhan sebagai model atau cara atau perbuatan dalam merawat dan mendidik anak, yang dalam hal ini adalah balita yang berumur 0-6 tahun. Pola asuh dalam penelitian ini diartikan sebagai sikap, perilaku, tindakan tertentu berkenaan dengan tugasnya sebagai orang tua dalam mendidik anaknya.

Keluarga merupakan lingkungan pendidikan utama dan pratama bagi perkembangan anak di masa yang akan datang. Menurut Hurlock (1997) dalam Helmilia (2006: 50) mengemukakan bahwa anak mengenal berbagai perilaku melalui peniruan terhadap tingkah laku khususnya tingkah laku orang tua. Perilaku anak sangat mungkin dipengaruhi oleh pola asuh orang tua karena dalam perkembangannya anak mengalami masa lekat dengan orang tuanya.

Berdasarkan suatu pendirian dalam psikologi (Koentjroningrat, 1986: 118) bahwa ciri-ciri dan unsur watak seorang individu dewasa sebenarnya sudah diletakkan benih-benihnya ke dalam jiwa seorang individu sejak awal, yaitu pada waktu ia masih anak-anak. Pembentukan watak dalam jiwa individu banyak dipengaruhi oleh pengalamannya ketika sebagai anak-anak, ketika ia diasuh orangorang dalam lingkungan keluarga, yaitu ibunya, ayahnya, kakak-kakaknya, dan individu-individu lain yang bisa mengerumuninya waktu itu.

Dari uraian di atas, jelaslah bahwa perilaku orang tua atau pola asuh orang tua yang diterima oleh anak mempengaruhi dan menentukan perkembangan anak selanjutnya.

\section{d. Konsep Pendidikan Anak Usia Dini}

Pendidikan Anak Usia Dini memegang peranan penting dan menentukan bagi sejarah perkembangan anak selanjutnya, sebab Pendidikan Anak Usia Dini merupakan fondasi bagi dasar kepribadian anak. Anak yang mendapatkan pembinaan sejak usia dini akan dapat meningkatkan kesehatan dan kesejahteraan fisik dan mental, yaitu akan berdampak pada peningkatan prestasi belajar, etos kerja dan produktifitas. Pada akhirnya anak akan lebih 
mampu untuk mandiri dan mengoptimalkan potensi yang dimiliki.

Untuk memberikan gambaran umum, dikemukakan pengertian Pendidikan Anak Usia Dini menurut beberapa ahli.Pendidikan Anak Usia Dini adalah pendidikan yang berfungsi membantu pertumbuhan dan perkembangan jasmani dan rohani peserta didik yang dapat dilakukan di dalam maupun di luar lingkungan. (Bahan sosialisasi pada PAUD direktorat pendidikan anak usia dini DIKLUSPORA, 2002).

\section{Metode}

Dalam penelitian ini peneliti menggunakan metode studi kasus yaitu menekankan pada aspek tertentu yang dikaji secara mendalam. Adapun pendekatan yang diambil adalah pendekatan kualitatif, karena pada hakekatnya penelitan ini bertujuan untuk menganalisis dan menafsirkan suatu fakta, gejala dan peristiwa berdasarkan apa yang terjadi dilapangan mengenai "Bagaimana Persepsi Keluarga Pemulung tentang Pendidikan Anak Usia Dini (Studi pada Keluarga Pemulung di Kampung Cibatu Desa Cilame Kecamatan Ngamprah Kabupaten Bandung Barat Barat)".

Dipilihnya metode ini sesuai dengan pendapat yang dikemukakan oleh Nana Sudjana dan Ibrahim (2001: 209) bahwa pada hakikatnya tujuan penelitian kualitatif adalah untuk :

a) Mendeskripsikan suatu proses kegiatan pendidikan berdasarkan apa yang terjadi dilapangan sebagai bahan kajian lebih lanjut untuk menemukan kekurangan dan kelemahan pendidikan, sehingga dapat ditentukan upaya penyempurnaannya.

b) Menganalisis dan menafsirkan suatu fakta, gejala dan peristiwa pendidikan yang terjadi dilapangan sebagaimana adanya daya konteks ruang dan waktu serta situasi lingkungan pendidikan secara alami.

c) Menyusun hipotesis berkenaan dengan konsep dan prinsip pendidikan berdasarkan data dan informasi yang terjadi di lapangan (induktif) untuk dilakukan pengujian lebih lanjut melalui pendekatan kualitatif.

\section{HASIL DAN PEMBAHASAN}

\section{Gambaran Umum Lokasi Penelitian}

Tempat tinggal atau perumahan merupakan salah satu faktor yang penting, selain menjadi indikator tingkat kemakmuran dan besarnya pendapatan seseorang. Tempat tinggal juga merupakan kebutuhan dasar (primer) yang harus dipenuhi oleh setiap individu (manusia), sehingga setiap individu akan senantisa berusaha unuk memiliki tempat tinggal walaupun sangat sederhana.

Semua rumah dan tanah tempat tinggal komunitas pemulung di Kampung Cibatu Desa Cilame Kecamatan Ngamprah Kabupaten Bandung Barat merupakaan sewaan kepada pemilik tanah. Ada yang hanya menyewa tanahnya saja dan ada yang menyewa rumah. Kebanyakan rumah sewa tersebut adalah rumah yang tidak permanent. Rumah itu terbuat dari papan dan beratapkan nipah walaupun ada yang beberapa beratapkan seng. Bagi warga yang hanya menyewa tanah, mereka membangun sendiri rumahnya dengan dinding bilik dan beratapkan daun nipah, lantainya dari semen kasar.

\section{Analisis Penelitian dan Pembahasan}

\section{a. Keadaan Keluarga Pemulung di Kampung Cibatu}

Dalam kehidupan berkelompok, bertahan hidup merupakan karakteristik dasar manusia. Manusia telah mewarisi dan mengembangkan cara-cara yang khas dalam kehidupan mereka dimana di dalam kelompok ternyata memerlukan partisipasi anggota masyarakat yang sudah dewasa dari kedua jenis kelamin. Robert R Jay (dalam Khairani, 2007) mengatakan bahwa ada keterkaitan erat antara keluarga inti dengan rumah tangga, yaitu sebagai sebuah kesatuan ekonomi dan sosial yang mandiri. Hampir semua orang hidup dalam keluarga dan rumah tangga, keanggotaan yang biasanya dilandasi hubungan kekerabatan perkawinan, dan keturunan yang secara simultan merupakan kombinasi satuan tempat tinggal, suatu kerjasama ekonomi (sekurang-kurangnya distribusi dan konsumsi) dengan satuan yang di dalamnya tedapat sebagian besar reproduksi dan sosialisasi anak sejak dini.

Kelompok kekerabatan yang terkecil yang terdapat di komunitas peumulung Kampung Cibatu adalah keluarga batih atau keluarga inti. Keluarga ini atau Nuclear Familiy adalah keluarga yang terdiri dari 
suami, istri, dan anak-anak yang belum menikah. Selain keluarga inti terdapat juga keluarga luas atau extended family. Keluarga luas ini adalah suatu keluarga yang terdiri dari seorang wanita, suaminya, anak-anak perempuan yang sudah menikah atau anak laki-laki yang menikah ditambah istrinya, yang terpenting disini adalah kesatuan ekonominya.

\section{Persepsi Keluarga Pemulung tentang Pendidikan Anak Usia Dini}

Pendidikan Anak Usia Dini memegang peranan penting dan menentukan bagi sejarah perkembangan anak selanjutnya, sebab Pendidikan Anak Usia Dini merupakan fondasi bagi dasar kepribadian anak. Anak yang mendapatkan pembinaan sejak usia dini akan dapat meningkatkan kesehatan dan kesejahteraan fisik dan mental, yaitu akan berdampak pada peningkatan prestasi belajar, etos kerja dan produktifitas. Pada akhirnya anak akan lebih mampu untuk mendiri dan mengoptimalkan potensi yang dimiliki.

Sekalipun pengaruh kemiskinan sangat besar terhadap anak-anak yang tidak memperoleh pendidikan, kemiskinan bukanlah satu-satunya faktor yang berpengaruh. Salah satu faktor yang berpengaruh adalah pola pikir yang pendek dan sederhana akibat rendahnya pendidikan. Dalam budaya Indonesia, kepala rumah tangga terutama seorang ayah, mempunyai peranan yang sangat besar dala rumah tangga termasuk dalam mengambil keputusan boleh atau tidaknya seorang anak untuk mendapat pendidikan. Untuk mengambil keputusan tersebut tentunya sangat tergantung kepada persepsi atau pandangan oranng tua terhadap pendidikan

\section{KESIMPULAN}

Dari hasil analisis yang dilakukan pada subjek penelitian diperoleh kesimpulan, sebagai berikut:

1. Persepsi Keluarga Pemulung tentang Pendidikan Anak Usia Dini

a. Anak merupakan investasi di dalam kehidupan, bagi keluarga pemulung hal tersebut dilakukan dengan memberikan berupa pendidikan pada usia dini, dimana pada usia antara 0-6 tahun merupakan usia yang sangat baik untuk mendidik serta membimbing mereka. Anak juga merupakan investasi yang digunakan untuk mencari rezeki, dengan ikutserta mencari rezeki (bekerja) anak menjadi lebih prihatin dan dapat menerima kenyataan.

b. Harapan keluarga pemulung yang paling terbesar adalah kelak anak-anak mereka dapat menyelesaikan sekolah mereka dengan baik, dan berprestasi serta mendapatkan pekerjaan yang lebih baik dari orang tua mereka, sehingga mereka dapat keluar dari garis kemiskinan dan pada akhirnya meningkatkan derajat keluarga mereka ditengah-tengah masyarakat. Namun dikenyataannya bahwa keluarga pemulung masih melibatkan anak-anak mereka dalam mencari nafkah, dimana para orang tua tidak memberikan waktu bagi anak-anak mereka untuk bermain dan belajar dengan baik tanpa harus ikut memikirkan dan berusaha dalam memenuhi kebutuhan hidup mereka.

2. Pola pengasuhan Anak Usia Dini (AUD) yang dilakukan oleh keluarga pemulung

Pola asuh menurut Nandang Hendriawan (1996: 14) mengandung arti model atau cara atau perbuatan dalam merawat dan mendidik anak, yang dalam hal ini adalah balita yang berumur 0-5 tahun. Pola asuh dalam penelitian ini diartikan sebagai sikap, perilaku, tindakan tertentu berkenaan dengan tugasnnya sebagai orang tua dalam mendidik anaknya.

Secara garis besar, bentuk pengasuhan orang tua tercermin dalam dua dimensi perlakuan orang tua. Dimensi yang pertama adalah tingkat dan tipe control yang dilaksanakan oleh orang tua terhadap perilaku anaknya. Pada satu sisi terdapat orang tua yang sangat mengontrol dan sangat menuntut anak, di sisi lain ada orang tua yang tidak pernah menuntut dan jarang mengontrol anak. Dimensi kedua, menyangkut keterlibatan orang tua dan tanggap tidaknya mereka terhadap anak. Pada satu sisi, beberapa orang tua sangat terlibat dengan anaknya, di sisi lain ada orang tua yang secara relative tidak terlibat dengan anaknya dan kadangkadang seolah-olah menolak anaknya. Dengan mengkombinasikan kedua sisi dari kedua dimensi tersebut secara konseptual dapat diklasifikasikan 3 kelompok pengasuhan orang tua yaitu Otoriter, Laizes Faire, dan Demokrasi.

Dari hasil penelitian di atas penulis akan mengelompokannya agar dapat terlihat keluargakeluarga tersebut lebih dominan otoriter, laizes 
faire, atau demokratis dalam memberikan pola pengasuhan anak-anaknya.

3. Pola pengasuhan Anak Usia Dini (AUD) yang dilakukan oleh keluarga pemulung

a. Pola pengasuhan yang dilakukan oleh keluarga pemulung yang mengikutsertakan anaknya ke lembaga PAUD adalah dominan menggunakan pola pengasuhan demokratis, sedangkan pola pengasuhan yang dilakukan oleh keluarag pemulung yang tidak mengikutsertakan anaknya ke lembaga PAUD adalah Otoriter dan Laizes Faire.

b. Pengasuhan yang lebih dominan terhadap anak yaitu dilakukan oleh ibu.

4. Peran serta orang tua (keluarga pemulung) dalam program PAUD di masyarakat

a. Semua keluarga pemulung di Kampung Cibatu Desa Cilame Kecamatan Ngamprah Kabupaten Bandung Barat memberikan partisipasi tenaga. Hal tersebut dikarenakan partisipasi dalam bentuk tenaga merupakan partisipasi yang murah dan mudah diberikan oleh keluarga pemulung.

b. Sebagian besar keluarga pemulung memberikan partisipasinya dalam bentuk keterampilan dan kemahiran serta sosial. Bagi keluarga pemulung yang menyertakan anaknya ke lembaga PAUD, hanya dapat membantu melalui ketrampilan yaitu membuat mainan dari barang-barang bekas serta sosial yaitu berupa menyebarkan informasi-informasi seputar penyelenggaraan kegiatan-kegiatan di PAUD.

c. Tidak ada keluarga pemulung yang berpartisipasi dalam buah pikiran dan harta benda. Hal tersebut dikarenakan tingkat pendidikan keluarga pemulung yang masih sangat rendah sehingga mereka tidak memiliki kepercayaan diri untuk berpartisipasi dalam hal buah pikiran dan tidak adanya kepercayaan dari pihak pengelola untuk memberikan kesempatan kepada keluarga pemulung dalam menyumbangkan buah pikiran mereka. Dalam hal harta benda mereka hanya bermata pencaharian sebagai pemulung bukan saja untuk menyumbangkan harta benda mereka, untuk penghidupan mereka sehari-haripun masih kekurangan
5. Peran serta orang tua (keluarga pemulung) dalam program PAUD di masyarakat.

Jenis-jenis partisipasi telah dikemukakan oleh Hamijoyo (1990), sebagai berikut:

a. Partisipasi buah pikiran, yaitu bahwa seseorang turut serta dalam menyumbangkan ide-ide bagi perkembangan masyarakat

b. Partisipasi tenaga, yaitu bentuk sumbangan berupa tenaga atau fisik.

c. Partisipasi ketrampilan dan kemahiran, yaitu memberikan ilmunya untuk kemajuan atau untuk diajarkan kepada oranglain.

d. Partisipasi harta benda, yaitu sumbangan berupa harta kekayaan bagi kelancaran suatu program atau untuk menunjang kelancaran suatu program.

e. Partisipasi sosial, yaitu keikutsertaan dalam suatu kegiatan yang bersifat sosial

\section{E. DAFTAR PUSTAKA}

Arikunto, S. (1998). Prosedur Penelitian (Suatu Pendekatan Praktek). Jakarta; Bina Aksara.

Departemen Pendidikan Nasional. (1989). Kamus Besar Bahasa Indonesia, Jakarta: Balai Pustaka.

Elshap, D.S. (2008). Peran Serta Orang Tua dalam Penyelenggraan Pendidikan Anak Usia Dini (PAUD) Terintegrasi dengan Posyandu. Skripsi Sarjana Pendidikan Universitas Pendidikan Indonesia. Bandung: Tidak diterbitkan.

Helmilia. (2006). Perbedaan Pola Asuh Anak Usia Dini dalam Keluarga dilihat dari Latar Belakang Pendidikan Ibu di Wilayah Rw 03 Kelurahan Cibatu Tarogong Kecamata Bojongloa Kaler Kota Bandung. Skripsi Sarjana Pendidikan Universitas Pendidikan Indonesia. Bandung: Tidak diterbitkan.

Indrawijaya. (1986). Psikologi Remaja. Jakarta: Raja Grafindo Persada.

Jarkasi. (1996). Peranan Pendidikan dalam Pembinaan Kebudayaan Nasional Daerah Kalimantan Selatan. DEPDIKBUD.

Hamijoyo. (1990). Partisipasi dalam Pembangunan. Jakarta: Depdikbud RI.

Hendriawan, N. (1996). Pola Pengasuhan AUD. Bandung.

Helmilia. (2006). Perbedaan Pola Asuh Anak Usia Dini dalam Keluarga.Bandung: UPI. 
Hurlock. E. B. (1997). Psikologi Perkembangan Suatu Pendekatan Sepanjang Rentang Kehidupan. Jakarta: Erlangga.

Kartono, K. (2002). Patologi Sosial dan Kenakalan Remaja. Bandung : Rajawali press.

Khairani. (2007). Persepsi Keluarga Pemulung tentang pendidikan. Medan: Universitas Sumatera Utara.

Koentjaraningrat. (1996). Pengantar Antropologi 1. Jakarta: Rineka Cipta.

Koentjaraningrat. (1997). Kebudayaan Mentalitas dan Pembangunan. Jakarta: Gramedia Pustaka Utama.

Maleong, L. J. (2007). Metodologi Penelitian Kualitatif. Bandung: Remaja Rosdakarya.

Mappaiere, A. (1982). Profesionalisasi Bimbingan Konseling dan Kode Etik : Jurnal Bimbingan.

Mar'at. (1981). Sikap manusia dan perubahan serta pengukurannya. Jakarta: Ghalia Indonesia.

Muhadjir, N. (1996), Metodelogi Penelitian Kualitatif. Yogyakarta: rake Sarasin.

Nana, S. dan Ibrahim. (2001). Penelitian dan Penilaian Pendidikan. Bandung; Sinar Baru Algesindo.

Nimrah (2007). Permasalahan Pendidikan. Medan: Universitas Sumatra Utara.

Peraturan Pemerintah No 27 Tahun 1990 tentang Pendidikan Pra Sekolah

Purwanto, ngalim. (1995). Ilmu Pendidikan Teoritis dan Praktis. Jakarta: PT. Remaja Rosda Karya Bandung.

Sadulloh, U., Robandi, B., dan Muharam, A. (2007). Pedagogik. Bandung: Cipta Utama.

Slamet, (1995). Belajar dan Faktor-faktor yang mempengaruhinya. Jakarta: Rineka Cipta.

Soekanto, S. (1994). Sosiologi Keluarga (tentang ikhwal keluarga remaja dan anak). Jakarta: Rineka Cipta.

Soelaeman, M. I. (1994). Pendidikan dalam Keluarga. Bandung:IKIP.

Spradley, James. (1997). Metode Etnografi. Yogya : PT. Tiara Wacana.

Sudjana, D. (2004) . Pendidikan Nonformal :Wawasan, Sejarah Perkembangan Falsafah \& Teori Pendukung, serta Asas. Bandung:Falah Production.

Sudjana, N. (2000). Metode dan Teknik Pembelajaran Partisipatif. Bandung: Falah Production.
Septiani, T. (2009). Persepsi Masyarakat terhadap peran kader BKB Kemas dalam Pelaksanaan dan Pencapaian Program Bina Keluarga Balita Kemas. Skripsi Sarjana Pendidikan Universitas Pendidikan Indonesia. Bandung: Tidak diterbitkan..

Undang-undang No.20 tahun 2003 tentang Sistem Pendidikan Nasional.

Usman, dkk. (2004). Pekerja Anak di Indonesia Kondisi, Determinan, dan Eksploitasi. Jakarta : PT. Gramedia.

Yunus, D. (2008). Dampak program pelatihan kecakapan hidup (life skill) ketrampilan terhadap perubahan sikap dan perilaku serta kemandirian berwirausaha. Skripsi Sarjana Pendidikan Universitas Pendidikan Indonesia. Bandung: Tidak diterbitkan.

Yusuf, S. (2000). Psikologi Perkembangan Anak dan Remaja. Bandung:Remaja Rosda Karya. 